\title{
Determinants of Trade Openness in Transitional Economies: Does the Complementarity between Foreign Direct Investment and Human Capital Development Matter?
}

Submitted 21/12/20, $1^{\text {st }}$ revision 21/01/21, $2^{\text {nd }}$ revision 22/02/21, accepted 20/03/21

\author{
Kunofiwa Tsaurai ${ }^{1}$
}

\begin{abstract}
:
Purpose: The study explored the determinants of trade openness in transitional economies. The impact of the complementarity between foreign direct investment (FDI) and human capital development on trade openness in transitional economies was also a subject of investigation.

Design/Approach/Methodology: The study used panel data analysis methods, namely the dynamic generalized methods of moments (GMM), fixed effects, pooled ordinary least squares $(O L S)$, random effects with panel data from 2000 to 2018.

Findings: Human capital development, the interaction between FDI and human capital development, economic growth and mining sector growth were found to have a significant positive impact on trade openness in transitional economies.

Practical Implication: Transitional economies are therefore urged to develop and implement policies earmarked at improving, FDI inflows, human capital development, economic growth, and mining sector growth if they intend not only to expand trade openness but to benefit from trade openness as well.

Originality/Value: The impact of the complementarity between FDI and human capital development on trade openness has so far not yet been explored, to the author's best knowledge.
\end{abstract}

Keywords: Trade openness, determinants, transitional economies, Panel data.

JEL codes: $B 17, F 21, J 24, P 2$.

Paper Type: Research Article.

\footnotetext{
${ }^{1}$ Associate Professor, Department of Finance, Risk Management and Banking, University of South Africa, South Africa, e-mail: tsaurk@unisa.ac.za
} 


\section{Introduction}

This section focuses on the background of the study, study's contribution towards literature and the general structure of the paper. The world over, the impact of trade openness on economic growth has been gaining momentum during the last four decades (Keho, 2017). As enunciated by Barro and Sala-i-Martin (1997), trade openness positively impacts on economic growth through enabling efficient allocation of resources, easy access to goods and services and facilitating the achievement of total factor productivity. Other studies argued that trade openness enhances growth of the economy through enhancing knowledge dissemination and technology diffusion (Musila and Yiheyis, 2015; Ulaşan, 2015; Polat et al., 2015). Except a few dissenting academic voices led by Jafari et al. (2012), most empirical researchers are of the view that trade openness enhances economic growth.

Consistent with Tahir et al. (2018), the fact that trade openness is one of the engines for economic growth means that government authorities and developmental oriented policymakers must have a critical understanding of the factors influencing trade openness if they are to be able to achieve their growth objective. Quite a few empirical researchers have so far studied the determinants of trade openness in order to fill in this void. The following major highlights relates to these few empirical studies on the determinants of trade openness. Firstly, their results are diverse, conflicting and quite mixed, thereby lacking conclusiveness. Secondly, majority of them ignored Osei et al. (2019) argument that trade openness is positively affected by its own lag. Thirdly, none of them exclusively focused on transitional economies, an economic group which immensely benefited from international economic integration in the last few decades. It is against this background that the current study seeks to empirically investigate the determinants of trade openness in transitional economies, in order to be able to develop and implement sustainable economic growth policies anchored on international economic integration.

There is no agreement on a common list of factors that have an impact on trade openness. Majority of the empirical studies on determinants of trade openness ignored endogeneity issues and the dynamic characteristics of the trade openness data. Non-linearity of the trade openness function was ignored by majority of the empirical researchers on the subject matter. Existing empirical research on the determinants of trade openness shied away from using transitional economies as a unit of analysis. In other words, no empirical study investigated the determinants of trade openness in transitional economies to the author's best knowledge. The impact of the complementarity between FDI and human capital development on trade openness has so far not yet been explored, to the author's best knowledge. The current study fills in these gaps.

Section 2 discusses the theoretical literature on the determinants of trade openness whilst section 3 deals with the empirical literature on the factors that influences trade openness. Description of the research methodology for the study is presented and 
explained in section 4. Section 5 is the data analysis (correlation analysis, panel unit root tests, panel co-integration tests, main data analysis using fixed effects, dynamic GMM, random effects, pooled OLS). Section 6 concludes the study.

\section{Literature Review}

\subsection{Theoretical Literature on the Determinants of Trade Openness}

The determinants of trade openness from a theoretical literature point of view are discussed in Table 1.

Table 1. Theoretical literature on the factors influencing trade openness

\begin{tabular}{|c|c|c|c|}
\hline Variable & $\begin{array}{l}\text { Proxy } \\
\text { used }\end{array}$ & Theory intuition & $\begin{array}{l}\text { Expec } \\
\text { ted } \\
\text { sign }\end{array}$ \\
\hline $\begin{array}{l}\text { Economic } \\
\text { growth } \\
\text { (GROWTH) }\end{array}$ & $\begin{array}{l}\text { GDP per } \\
\text { capita }\end{array}$ & $\begin{array}{l}\text { Economic growth triggers expansion of the local industry, } \\
\text { which can only be sustained if a country can be able to } \\
\text { expand the market of its products beyond its borders. Such a } \\
\text { strategy enhances trade openness of that country, argued } \\
\text { (Yanikkaya, 2003). An empirical study carried out by } \\
\text { Zannou (2010) noted that economic growth had a significant } \\
\text { positive effect on trade openness levels among Economic } \\
\text { Community of West African Countries (ECOWAS) group of } \\
\text { nations. Tahir et al (2018) argued that high income countries } \\
\text { are generally engaged in more trade. }\end{array}$ & + \\
\hline $\begin{array}{l}\text { Foreign direct } \\
\text { investment } \\
\text { (FDI) }\end{array}$ & $\begin{array}{l}\text { Net FDI } \\
\text { inflows } \\
(\% \text { of } \\
\text { GDP) }\end{array}$ & $\begin{array}{l}\text { A study done by Ghosh (2007) observed that FDI had a } \\
\text { significant positive influence on trade openness in } \\
\text { developing countries. Even after capturing control variables } \\
\text { such as GDP per capita, inflation, macroeconomic volatility, } \\
\text { FDI was still found to have had a positive influence on trade } \\
\text { openness in developing nations. }\end{array}$ & + \\
\hline $\begin{array}{l}\text { Human capital } \\
\text { development } \\
\text { (HCD) }\end{array}$ & $\begin{array}{l}\text { Human } \\
\text { capital } \\
\text { develop } \\
\text { ment } \\
\text { index }\end{array}$ & $\begin{array}{l}\text { Highly educated labour force is more productive and is } \\
\text { closely correlated with industrial sector production (Tahir et } \\
\text { al. 2018: 154). The same study argued that the high level of } \\
\text { production triggered by highly educated workforce enables } \\
\text { the country to satisfy both the local and international demand } \\
\text { of its products. }\end{array}$ & + \\
\hline $\begin{array}{l}\text { Population } \\
\text { growth and } \\
\text { size }(\mathrm{PG})\end{array}$ & $\begin{array}{l}\text { Populati } \\
\text { on } \\
\text { growth } \\
\text { (annual } \\
\% \text { ) }\end{array}$ & $\begin{array}{l}\text { Highly populated countries such as China and Nigeria tend } \\
\text { to have enough size of the market internally thereby } \\
\text { reducing the overreliance on external markets (Zannou. } \\
\text { 2010). The view was also supported by Rao and Kumar } \\
\text { (2009). }\end{array}$ & + \\
\hline $\begin{array}{l}\text { Agriculture } \\
\text { growth } \\
\text { (AGRIC) }\end{array}$ & $\begin{array}{l}\text { Agricult } \\
\text { ure }(\% \\
\text { of GDP })\end{array}$ & $\begin{array}{l}\text { According to Mbogela (2019), a country characterised by } \\
\text { high agricultural proportion as a percentage of GDP is } \\
\text { expected to have low trade openness values. This because } \\
\text { such a country is self-sufficient in terms of food production } \\
\text { and security and does not over depend on other countries to } \\
\text { import food. Mbogela (2019) argued that agricultural } \\
\text { products are no longer dominant in the world trade ratios. } \\
\text { The same study noted that high levels of agricultural } \\
\text { production in proportion to GDP triggers the need to export } \\
\text { the excess produce remaining after local consumption. }\end{array}$ & $+/-$ \\
\hline
\end{tabular}




\begin{tabular}{|l|l|l|l|}
\hline $\begin{array}{l}\text { Mining sector } \\
\text { growth (MIN) }\end{array}$ & $\begin{array}{l}\text { Mining } \\
\text { rent (\% } \\
\text { of GDP) }\end{array}$ & $\begin{array}{l}\text { Consistent with Squalli and Wilson (2011), international } \\
\text { markets is the final and sustainable place where minerals are } \\
\text { traded. It means that locally extracted minerals eventually } \\
\text { find themselves being traded at the global markets to fetch } \\
\text { sustainable prices. It is for this reason that substantial } \\
\text { mineral producing countries are normally characterised by } \\
\text { high levels of trade openness (Mbogela, 2019: 34). }\end{array}$ & + \\
\hline $\begin{array}{l}\text { Exchange } \\
\text { rates (EXCH) }\end{array}$ & $\begin{array}{l}\text { Official } \\
\text { exchang } \\
\text { e rate } \\
\text { (LCU } \\
\text { per US\$, } \\
\text { period } \\
\text { average) }\end{array}$ & $\begin{array}{l}\text { According to Abbott (2004), exchange rate volatility stifle } \\
\text { trade because companies are not certain about the true value } \\
\text { of the transactions in the future, thereby it becomes difficult } \\
\text { for them to plan. }\end{array}$ & - \\
\hline
\end{tabular}

Source: Author's compilation.

Theoretical literature on the determinants of trade openness summarized in Table 1 has some weaknesses. Firstly, the nature of the relationship between trade openness and its macroeconomic determinants is not discussed at all. Secondly, the endogeneity problem which normally characterizes the function describing trade openness and its explanatory variables is ignored. Thirdly, the dynamic nature of the trade openness data, consistent with Osei et al. (2019) is totally excluded. Fourthly, the non-linearity between trade openness and its independent variables is not captured. This study captures all these issues and fills in the existing gaps.

\subsection{Empirical Literature on the Determinants of Trade Openness}

As can be seen in Table 2, empirical literature on the determinants of trade openness is very scant. The research has been empirically investigated by six studies (Osei et al., 2019; Tahir et al., 2018; Mbogela, 2019; Prasad and Gable, 1998; Nga, 2020; Saber, 2010) to the best of the author's knowledge.

Table 2. Determinants of trade openness - Empirical literature

\begin{tabular}{|c|c|c|c|c|}
\hline $\begin{array}{l}\text { Autho } \\
\mathrm{r}\end{array}$ & $\begin{array}{l}\text { Country/Coun } \\
\text { tries of study }\end{array}$ & Period & $\begin{array}{l}\text { Methodol } \\
\text { ogy }\end{array}$ & Results \\
\hline $\begin{array}{l}\text { Osei } \\
\text { et al } \\
(2019)\end{array}$ & $\begin{array}{l}\text { Lower } \\
\text { middle- } \\
\text { income } \\
\text { countries }\end{array}$ & $\begin{array}{l}1980- \\
2015\end{array}$ & $\begin{array}{l}\text { Panel data } \\
\text { analysis }\end{array}$ & $\begin{array}{l}\text { The lag of trade openness and economic growth } \\
\text { were found to have had a significant positive } \\
\text { impact on trade openness. }\end{array}$ \\
\hline $\begin{array}{l}\text { Tahir } \\
\text { et al } \\
(2018)\end{array}$ & $\begin{array}{l}\text { South Asian } \\
\text { Association } \\
\text { for Regional } \\
\text { Cooperation }\end{array}$ & $\begin{array}{l}1971- \\
2011\end{array}$ & $\begin{array}{l}\text { Panel data } \\
\text { analysis }\end{array}$ & $\begin{array}{l}\text { Financial development, human capital } \\
\text { development, gross domestic product (GDP) per } \\
\text { capita, labour force size and exchange rates are } \\
\text { the variables which were found to have had a } \\
\text { significant positive impact on trade openness. }\end{array}$ \\
\hline $\begin{array}{l}\text { Mbog } \\
\text { ela } \\
(2019)\end{array}$ & Africa & $\begin{array}{l}1989- \\
2009\end{array}$ & $\begin{array}{l}\text { Panel data } \\
\text { analysis }\end{array}$ & $\begin{array}{l}\text { GDP per capita, population size, economic } \\
\text { location, mining sector growth and agricultural } \\
\text { production were all found to have enhanced trade } \\
\text { openness in Africa. }\end{array}$ \\
\hline Prasad & High Income & $1970-$ & Structural & Economic growth and exchange rates were found \\
\hline
\end{tabular}




\begin{tabular}{|l|l|l|l|l|}
\hline $\begin{array}{l}\text { and } \\
\text { Gable } \\
(1998)\end{array}$ & countries & 1995 & $\begin{array}{l}\text { Vector } \\
\text { Autoregre } \\
\text { ssion } \\
\text { Models }\end{array}$ & to be positive drivers of trade openness. \\
\hline $\begin{array}{l}\text { Nga } \\
(2020)\end{array}$ & Vietnam & $\begin{array}{l}2005- \\
2008\end{array}$ & $\begin{array}{l}\text { Time } \\
\text { series data } \\
\text { analysis }\end{array}$ & $\begin{array}{l}\text { Foreign direct investment and openness of the } \\
\text { economy had a significant negative influence on } \\
\text { trade balance. Exchange had an insignificant } \\
\text { impact on trade balance in Vietnam. }\end{array}$ \\
\hline $\begin{array}{l}\text { Saber } \\
(2010)\end{array}$ & Sudan & $\begin{array}{l}1970- \\
2007\end{array}$ & $\begin{array}{l}\text { Ordinary } \\
\text { Least } \\
\text { Squares } \\
\text { (OLS) }\end{array}$ & $\begin{array}{l}\text { Population growth, GDP per capita and real } \\
\text { exchange rate were the major determinants that } \\
\text { were behind significant increase in trade } \\
\text { openness in Sudan. }\end{array}$ \\
\hline
\end{tabular}

Source: Author's compilation.

The following highlights are pertinent regarding the empirical literature on the factors influencing trade openness discussed in Table 2. Empirical research on the subject matter is quite scant. The results from the available empirical research on the determinants of trade openness are diverse and shows that the subject matter is not yet conclusive. The current study seeks to contribute to literature by investigating trade openness's determinants using transitional economies as a focal point.

\section{Description of the Research Methodology}

Consistent with findings from empirical research done by Osei et al. (2019), Mbogela (2019), Tahir et al. (2018), Saber (2010). and Nga (2020), the general model specification of the trade openness function is represented by equation 1 .

OPEN=f (FDI, HCD, PG, GROWTH, EXCH, AGRIC, MIN)

The abbreviations have already been described in Table 1 . In this study, trade openness (OPEN) is measured using three proxies, namely total trade (\% of GDP), exports of goods and services (\% of GDP) and imports of goods and services (\% of GDP). FDI is measured using net FDI inflows (\% of GDP), human capital development index is the proxy of human capital development used whilst population growth was measured using population growth (annual \%). GDP per capita was used to measure economic growth whereas exchange rate was proxied by official exchange rate (LCU per US\$, period average). Agriculture (\% of GDP) was used to measure agriculture sector growth. Mining rent ( $\%$ of GDP) is the measure of mining sector growth employed in this study.

Econometric representation of equation 1 is shown in the form of equation 2.

$$
\begin{aligned}
& \text { OPEN }_{\mathrm{it}}=\beta_{0}+\beta_{1} \mathrm{OPEN}_{\mathrm{it}-1}+\beta_{2} \mathrm{FDI}_{\mathrm{it}}+\beta_{3} \mathrm{HCD}_{\mathrm{it}}+\beta_{4}\left(\mathrm{FDI}_{\mathrm{it}} \cdot \mathrm{HCD}_{\mathrm{it}}\right)+\beta_{5} \mathrm{PG}_{\mathrm{it}} \\
& +\beta_{6} \mathrm{GROWTH}_{\mathrm{it}}+\beta_{7} \mathrm{EXCH}_{\mathrm{it}}+\beta_{8} \mathrm{AGRIC}_{\mathrm{it}}+\beta_{9} \mathrm{MIN}_{\mathrm{it}}+\boldsymbol{\mu}+\varepsilon
\end{aligned}
$$


The one period lag of trade openness represents the convergence effect of openness in transitional economies, consistent with Osei et al. (2019). The possibility of a complementarity between FDI and human capital development having an influence on trade openness was first raised by Dinh et al. (2015).

Whilst $\beta_{0}$ is an intercept, $\beta_{1}$ to $\beta_{9}$ are the coefficients for the respective independent variables in the trade openness function. A significant negative value of $\beta_{4}$ implies that the combination of FDI and human capital development reduces the extent of trade openness in transitional economies. On the other hand, if $\beta_{4}$ is positive and positive, it shows that the complementarity between FDI and human capital development enhances trade openness in transitional economies. Equation 2 is estimated using the dynamic GMM methodology, whose advantages include its ability to address the endogeneity problem and the dynamic features of trade openness data.

The only difference between equation 2 and 3 is that the latter excludes the lag of trade openness.

$$
\begin{aligned}
& \mathrm{OPEN}_{\mathrm{it}}=\beta_{0}+\beta_{1} \mathrm{FDI}_{\mathrm{it}}+\beta_{2} \mathrm{HCD}_{\mathrm{it}}+\beta_{3}\left(\mathrm{FDI}_{\mathrm{it}} \cdot \mathrm{HCD}_{\mathrm{it}}\right)+\beta_{4} \mathrm{PG}_{\mathrm{it}}+\beta_{5} \mathrm{GROWTH}_{\mathrm{it}} \\
& +\beta_{6} \mathrm{EXCH}_{\mathrm{it}}+\beta_{7} \mathrm{AGRIC}_{\mathrm{it}}+\beta_{8} \mathrm{MIN}_{\mathrm{it}}+\boldsymbol{\mu}+\varepsilon
\end{aligned}
$$

Fixed effects, pooled OLS and random effects panel data analysis methods were used to estimate equation 3. This was done for results comparison purposes, consistent with Tsaurai (2018).

Data analysis discussion: Panel data (2000 to 2018) was used in this empirical investigation. The period was chosen because it is within the timeframe when transitional economies experienced accelerated economic growth and integration into the global international commodity and financial markets. World Bank Development Indicators, United Nations Development Programme, African Development Indicators, International Financial Statistics, South African Reserve Bank and South Africa Statistics Agency. As per Aye and Edoja (2017) view, these sources of secondary data (databases) are reputable and have an international outlook in stature.

Correlation analysis: From Table 3, the maximum correlation value regardless of the direction of the relationship is $67.92 \%$ (between mining sector growth and FDI). Consistent with Stead (1996), there is no multicollinearity problem between the variables under study.

In support of the available theoretical and empirical literature (refer to Table 1 and 2), FDI, population growth, human capital development, economic growth, mining sector growth and agricultural production were each positively correlated with trade 
openness. The negative correlation between exchange rate and trade openness is also supported by available theoretical arguments (see Table 1).

Table 3. Correlation results

\begin{tabular}{|l|l|l|l|l|l|l|l|l|}
\hline & OPEN & FDI & HCD & PG & GROWTH & EXCH & AGRIC & MIN \\
\hline OPEN & 1.00 & & & & & & & \\
\hline FDI & $0.56^{* * *}$ & 1.00 & & & & & & \\
\hline HCD & 0.05 & $0.12^{* * *}$ & 1.00 & & & & & \\
\hline PG & $0.63^{* * *}$ & 0.01 & -0.35 & 1.00 & & & & \\
\hline $\begin{array}{l}\text { GRO } \\
\text { WTH }\end{array}$ & $0.35^{* * *}$ & $0.28^{* *}$ & $0.23^{* * *}$ & $0.27^{* *}$ & 1.00 & & & \\
\hline EXCH & -0.29 & -0.45 & -0.18 & 0.45 & 0.35 & 1.00 & & 1.00 \\
\hline $\begin{array}{l}\text { AGRI } \\
\text { C }\end{array}$ & 0.23 & 0.12 & -0.42 & $0.35^{*}$ & $0.23^{* * *}$ & -0.35 & 1.00 \\
\hline MIN & $0.56^{* * *}$ & $0.68^{* *}$ & $0.10^{* * *}$ & $0.45^{* * *}$ & $0.17^{* * *}$ & 0.20 & -0.50 & 1.00 \\
\hline
\end{tabular}

Note: $* * * / * * *$ denotes statistical significance at the $1 \% / 5 \% / 10 \%$ level, respectively.

Source: Author's compilation from E-Views.

Panel unit root tests: Consistent with other empirical studies on similar or different subject matter, panel unit roots used in this study include Levin et al (2002), Im et al (2003), Augmented Dick Fuller Fisher Chi Square and Phillip Peron (PP) Chi square tests.

Table 4. Panel root tests-Individual intercept

\begin{tabular}{|c|c|c|c|c|}
\hline \multicolumn{5}{|l|}{ Level } \\
\hline & LLC & IPS & ADF & PP \\
\hline OPEN & -2.3198 & -0.2298 & 10.3267 & 5.1128 \\
\hline FDI & -1.2187 & 0.4387 & 7.2875 & 5.4982 \\
\hline HCD & $-2.1278 * *$ & $-2.2982 * * *$ & $22.1176^{* *}$ & $35.7609 * * *$ \\
\hline PG & 1.2765 & 3.3285 & 1.6654 & 0.0067 \\
\hline GROWTH & -0.8972 & -0.2786 & 8.1128 & 7.7632 \\
\hline $\mathrm{EXCH}$ & $-1.3282 * *$ & $-3.6719 * * *$ & $27.2178 * * *$ & $75.2896 * * *$ \\
\hline AGRIC & -1.2178 & $-1.6652 *$ & $20.1908 * *$ & 10.5523 \\
\hline MIN & $-2.1190 * *$ & $-4.0092 * * *$ & $-3.1199 * *$ & $-8.1184 * * *$ \\
\hline \multicolumn{5}{|c|}{ First difference } \\
\hline OPEN & $-4.8734 * *$ & $-4.7892 * * *$ & $37.47619 * * *$ & $128.5532 * * *$ \\
\hline FDI & $-3.2376 * * *$ & $-4.7782 * * *$ & $35.9810 * * *$ & $201.6781 * * *$ \\
\hline HCD & $-1.9813^{*}$ & $-4.4387 * * *$ & $33.9913 * * *$ & $317.7792 * * *$ \\
\hline PG & $-2.9014 * *$ & $-2.1176 * *$ & $18.9902 * *$ & $28.8293 * * *$ \\
\hline GROWTH & $-3.8719 * * *$ & $-3.8734 * * *$ & $29.7613 * * *$ & $59.6722 * * *$ \\
\hline $\mathrm{EXCH}$ & $-5.9003 * * *$ & $-5.6773 * * *$ & $45.9334 * * *$ & $173.1128 * * *$ \\
\hline AGRIC & $-3.3367 * * *$ & $-3.9603 * * *$ & $35.2164 * * *$ & $59.1732 * * *$ \\
\hline MIN & $-6.9815 * * *$ & $-9.9834 * * *$ & $-8.0023 * * *$ & $-15.9817 * * *$ \\
\hline
\end{tabular}

Note: LLC, IPS, ADF and PP stands for Levin, Lin and Chu; Im, Pesaran and Shin; ADF

Fisher Chi Square and PP Fisher Chi Square tests respectively. *, ** and *** denote 10\%, $5 \%$ and $1 \%$ levels of significance, respectively.

Source: Author's compilation from E-Views. 
The results in Table 4 are integrated of order 1, hence allowing data analysis process to proceed to panel co-integration, in line with Malefane and Odhiambo (2018).

Panel co-integration tests: This study used Kao (1999) panel co-integration tests to investigate whether a long run relationship between and or among the variables studied exist (results are presented in Table 5).

Table 5. Results of Kao (1999) co-integration tests

\begin{tabular}{|l|l|}
\hline Series & ADF t-statistic \\
\hline OPEN1 FDI HCD PG GROWTH EXCH AGRIC MIN & $-4.0983 * * *$ \\
\hline OPEN2 FDI HCD PG GROWTH EXCH AGRIC MIN & $-7.1176^{* * *}$ \\
\hline OPEN3 FDI HCD PG GROWTH EXCH AGRIC MIN & $-3.1128 * * *$ \\
\hline
\end{tabular}

Source: Author's compilation.

OPEN 1, OPEN 2 and OPEN 3 stands for trade openness as measured by total trade (\% of GDP), total exports of goods and services (\% of GDP) and total imports of goods and services (\% of GDP) respectively. The panel co-integration results show that a null hypothesis which states that there exists a long run relationship between the variables under study cannot be rejected at 1 percent significance level, in line with Tembo (2018). Similar results were also found by similar empirical research done by Osei et al (2019), Mbogela (2019) and Tahir et al (2018).

Main data analysis: Model 1 uses total trade (\% of GDP), model 2 employs total exports of goods and services (\% of GDP) whilst model 3 uses total imports of goods and services. Results are presented in Tables 6, 7, 8 and 9.

Table 6. Dynamic Generalized Methods of Moments results

\begin{tabular}{|l|l|l|l|}
\hline & Model 1 & Model 2 & Model 3 \\
\hline OPEN $_{\text {it-1 }}$ & $0.0216 * * *$ & $0.0021 * * *$ & $0.2178 * * *$ \\
\hline FDI & $0.2317 *$ & 0.1482 & 0.5995 \\
\hline HCD & $0.3178 * *$ & $0.2177 *$ & $0.2163 * *$ \\
\hline FDI.HCD & $0.4721 * * *$ & $0.1789 * *$ & $0.0931 * * *$ \\
\hline PG & -0.1782 & -0.3233 & -0.5993 \\
\hline GROWTH & 0.3328 & 0.3888 & 0.1784 \\
\hline EXCH & -0.3422 & -0.3118 & -0.6289 \\
\hline AGRIC & 0.1889 & 0.4176 & 0.1199 \\
\hline MIN & $0.2187 * * *$ & $0.0338 * *$ & $0.3499 * * *$ \\
\hline $\begin{array}{l}\text { Adjusted R- } \\
\text { squared }\end{array}$ & 0.63 & 0.59 & 0.64 \\
\hline F-statistic & 145 & 153 & 147 \\
\hline $\begin{array}{l}\text { Prob } \\
\text { statistic) }\end{array}$ & 0.00 & 0.00 & 0.00 \\
\hline and denote & $0,5 \%$ and & & \\
\hline
\end{tabular}

Note: $* * *, * *$ and $*$ denote $1 \%, 5 \%$ and $10 \%$ levels of significance, respectively.

Source: Author's compilation from E-Views. 
In Table 6, trade openness was found to have been positively and significantly affected by its own lag, consistent with Osei et al (2019) whose study argued that the one period lag of trade openness represents the convergence effect of openness.

Using the dynamic GMM approach, FDI had a significant positive impact on trade openness in model 1 whilst model 2 and 3 show a non-significant positive relationship running from FDI towards trade openness. The results resonate with Ghosh's (2007) findings. Across all the three models, human capital development was found to have had a significant positive effect on trade openness, in line with Tahir et al (2018) whose study argued that high level of production triggered by highly educated workforce enables the country to satisfy both the local and international demand of its products.

Table 7. Fixed effects results

\begin{tabular}{|l|l|l|l|}
\hline & Model 1 & Model 2 & Model 3 \\
\hline FDI & 0.0867 & $0.1288^{*}$ & $0.2174^{*}$ \\
\hline HCD & 0.2386 & 0.0005 & $0.2177^{*}$ \\
\hline FDI.HCD & $0.1683^{* * *}$ & $0.5222^{* * *}$ & $0.1155^{* * *}$ \\
\hline PG & -0.4462 & -0.3322 & -0.5898 \\
\hline GROWTH & $0.0221^{* * *}$ & $0.2211^{* * *}$ & $0.4439^{* * *}$ \\
\hline EXCH & -0.1116 & -0.5411 & -0.3411 \\
\hline AGRIC & $0.3422^{* * *}$ & 0.1698 & 0.4377 \\
\hline MIN & $0.1776^{* * *}$ & 0.0333 & 0.4318 \\
\hline $\begin{array}{l}\text { Adjusted R- } \\
\text { squared }\end{array}$ & 0.59 & 0.67 & 0.63 \\
\hline F-statistic & 111 & 98 & 124 \\
\hline $\begin{array}{l}\text { Prob (F- } \\
\text { statistic) }\end{array}$ & 0.00 & 0.00 & 0.00 \\
\hline
\end{tabular}

Note: $* * *, * *$ and $*$ denote $1 \%, 5 \%$ and $10 \%$ levels of significance, respectively.

Source: Author's compilation from E-Views.

Table 8. Random effects results

\begin{tabular}{|l|l|l|l|}
\hline & Model 1 & Model 2 & Model 3 \\
\hline FDI & -0.5644 & -0.4387 & $0.4288^{*}$ \\
\hline HCD & $0.3421^{*}$ & $0.2398^{* *}$ & $0.4586^{* *}$ \\
\hline FDI.HCD & $0.1189^{* * *}$ & $0.3256^{* * *}$ & $0.2318^{* * *}$ \\
\hline PG & -0.4567 & -0.2218 & -0.4477 \\
\hline GROWTH & $0.0007 * * *$ & $0.4999^{* * *}$ & $0.2255^{* * *}$ \\
\hline EXCH & -0.1732 & -0.3218 & -0.1893 \\
\hline AGRIC & 0.0022 & 0.1682 & 0.3715 \\
\hline MIN & $0.3622^{* * *}$ & $0.3228^{* * *}$ & $0.2829 * * *$ \\
\hline Adj. R squared & 0.62 & 0.57 & 0.63 \\
\hline F-statistic & 165 & 106 & 128 \\
\hline Prob(F-statistic) & 0.00 & 0.00 & 0.00 \\
\hline
\end{tabular}

Note: $* * * * *$ and $*$ denote $1 \%, 5 \%$ and $10 \%$ levels of significance, respectively.

Source: Author's compilation from E-Views. 
Table 9. Pooled OLS results

\begin{tabular}{|l|l|l|l|}
\hline & Model 1 & Model 2 & Model 3 \\
\hline FDI & 0.0018 & 0.3123 & 0.1992 \\
\hline HCD & 0.1889 & 0.2243 & 0.5991 \\
\hline FDI.HCD & $0.3287^{* * *}$ & $0.2876^{* * *}$ & $0.3287^{* * *}$ \\
\hline PG & -0.1892 & -0.3218 & -0.1792 \\
\hline GROWTH & $0.3211^{* * *}$ & $0.3178^{* * *}$ & $0.1782^{* * *}$ \\
\hline EXCH & -0.2898 & -0.4998 & -0.1628 \\
\hline AGRIC & 0.1410 & 0.4727 & 0.1672 \\
\hline MIN & $0.3262^{* * *}$ & $0.33610^{* * *}$ & $0.1272^{* * *}$ \\
\hline $\begin{array}{l}\text { Adjusted R- } \\
\text { squared }\end{array}$ & 0.65 & 0.62 & 0.58 \\
\hline F-statistic & 123 & 144 & 135 \\
\hline $\begin{array}{l}\text { Prob (F- } \\
\text { statistic) }\end{array}$ & 0.00 & 0.00 & 0.00 \\
\hline
\end{tabular}

Note: $* * *, * *$ and $*$ denote $1 \%, 5 \%$ and $10 \%$ levels of significance, respectively.

Source: Author's compilation from E-Views.

Under fixed effects in model 1 and pooled OLS in model 1,2 and 3, FDI was observed to have had a non-significant positive effect on trade openness whereas fixed effects in model 2 and 3 shows a significant positive correlation running from FDI towards trade openness. The results resonate with Ghosh (2007) argument that FDI and trade openness are positively correlated as they both show the general level of an economy's openness to the outside world. In contradiction to available literature, random effects approach in model 1 and 2 indicates that FDI is negatively and non-significantly related to trade openness.

Fixed effects in model 1 and 2 and pooled OLS across all the three models, the results produced indicates that human capital development had a non-significant positive effect on trade openness. In addition, fixed effects in model 3 and random effects across all the three models, a significant positive relationship running from human capital development towards trade openness was observed. The results are in line with Tahir et al. 's (2018) argument.

Consistent with Dinh et al. (2015) reasoning, the complementarity between FDI and human capital development had a significant positive influence on trade openness across all the three models. These results were produced under all the four panel data analysis methods employed and across all the three models of the study.

Dynamic GMM produced results which show that economic growth influenced trade openness in a positive but insignificant manner across all the three models. However, the remaining econometric approaches used (pooled OLS, random effects, fixed effects) shows that economic growth had a significant positive impact on trade openness across all the three models. These results are in line with Yanikkaya (2003) whose study argued that economic growth enhances local industry growth, which 
can only be sustained if a country can be able to expand the market of its products beyond its borders.

Under all the four econometric methods used (dynamic GMM, fixed effects, pooled OLS, random effects) and across all the three models, a non-significant negative relationship running from population growth towards trade openness was detected, in line with Zannou (2010) and Rao and Kumar (2009) whose research argued that highly populated countries have sufficient domestic market size thereby reducing the overreliance on external markets.

Consistent with Abbott (2004) whose study explained that exchange rate volatility stifle trade because companies are not certain about the true value of the transactions in the future, this study shows that exchange rate had a non-significant negative effect on trade openness under all the four econometric estimation methods employed and across all the three models. Except fixed effects, model 1 (which shows a significant positive impact), all the other results under the dynamic GMM, random effects, fixed effects and pooled OLS indicates that agricultural production influenced trade openness in a positive but insignificant manner. The results (direction of causality) generally resonate with Mbogela (2019) whose research noted that agricultural production in proportion to GDP triggers the need to export the excess produce remaining after local consumption.

Under fixed effects model 1, mining sector growth had a significant positive influence on trade openness whilst model 2 and 3 shows that mining sector growth affected trade openness in a positive but non-significant manner. Moreover, pooled OLS, dynamic GMM and random effects show a significant positive relationship running towards trade openness from mining sector growth across all the three models of the study. These results resonate with Mbogela (2019) view that substantial mineral producing countries are normally characterized by high levels of trade openness because international markets is the final and sustainable place where minerals are traded.

\section{Conclusion}

The study explored the determinants of trade openness in transitional economies using panel data analysis methods (dynamic GMM, fixed effects, pooled OLS, random effects) with panel data from 2000 to 2018 in transitional economies. The impact of the complementarity between FDI and human capital development on trade openness in transitional economies was also a subject of investigation. Empirical studies on the determinants of trade openness are quite scant. Mixed results in the existing empirical literature on the determinants of trade openness also triggered research on the determinants of trade openness. Moreover, the story on the determinants of trade openness has not been told at all in the case of transitional economies. 
Human capital development, the interaction between FDI and human capital development, economic growth and mining sector growth were found to have a significant positive impact on trade openness in transitional economies. Transitional economies are therefore urged to develop and implement policies earmarked at improving, FDI inflows, human capital development, economic growth and mining sector growth if they intend not only to expand trade openness but to benefit from trade openness as well.

\section{References:}

Abbott, A. 2004. The impact of exchange rate volatility on UK exports to EU countries. Journal of Political Economy, 51, 62-81.

Aye, G.C., Edoja, P.E. 2017. Effect of economic growth on C02 emission in developing countries: Evidence from a dynamic panel threshold model. Cogent Economics and Finance, 5 (1), 1-22.

Barro, R.J., Sala-i-Martin, X. 1997. Technological diffusion, convergence, and growth. Journal of Economic Growth, 2(1), 1-26

Dinh, T.S. Thi, B., Hoai, M. 2015. Foreign direct investment, trade openness and economic growth: Empirical evidence from Asia-Pacific developing countries. 2nd Asia Conference on Business and Economic Studies, $13^{\text {th }}-14$ th September, Ho Chi Minh City, Vietnam.

Ghosh, I. 2007. The relation between trade and FDI in developing countries - A panel data approach. Global Economy Journal, 7(3), 1-30.

Im, K.S., Pesaran, M.H., Shin, Y. 2003. Testing unit roots in heterogeneous panels. Journal of Econometrics, 115(1), 53-74.

Jafari, S.A., Ghaderi, S., Hosseinzadeh, R., Nademi, Y. 2012. Openness and inflation: New empirical panel data evidence. Economics Letters, 117, 573-577.

Kao, C. 1999. Spurious regression and residual-based tests for co-integration in panel data. Journal of Econometrics, 90(1), 1-44.

Keho, Y. 2017. The impact of trade openness on economic growth: The case of Cote d'Ivoire. Cogent Economics and Finance, 5(1), 1-14.

Levin, A., Lin, C.F., Chu, C.S.J. 2002. Unit root tests in panel data: Asymptotic and finitesample properties. Journal of Econometrics, 108(1), 1-24.

Malefane, M.R., Odhiambo, N. 2018. Impact of trade openness on economic growth: Empirical evidence from South Africa. International Economics, 71(4), 387-416.

Mbogela, C.S. 2019. An empirical study on the determinants of trade openness in the African economies. Advances in Management and Applied Economies, 9(3), 9-42.

Musila, J.W., Yiheyis, Z. 2015. The impact of trade openness on growth: The case of Kenya. Journal of Policy Modelling, 37, 342-354.

Nga, N.T.V. 2020. Analysis of the determinants of trade balance: A case study of Vietnam. Journal of Applied Finance and Banking , 10(3), 21-35.

Osei, D.B., Sare, Y.A., Ibrahim, M. 2019. On the determinants of trade openness in low and lower middle-income countries in Africa: How important is economic growth? Future Business Journal, 5(2), 1-10.

Polat, A., Shahbaz, M., Rehman, I.U., Satti, S.L. 2015. Revisiting linkages between financial development, trade openness and economic growth in South Africa: Fresh evidence from combined cointegration test. Quality and Quantity, 49, 785-803.

Prasad, E.S., Gable, J.A. 1998. International evidence on the determinants of trade dynamics. 
IMF Staff Papers, 45(3), 401-439.

Rao, B.B., Kumar, S. 2009. A panel data approach to the demand for money and the effects of financial reforms in the Asian countries. Economic Modelling, 26, 1012-1017.

Saber, S.A. 2010. Determinants of trade openness in Sudan: An empirical investigation (1970-2007). Gezira Journal of Economic and Social Sciences, 1(1), 1-21.

Squalli, J., Wilson, K. 2011. A New Measure of Trade Openness. The World Economy, 34, 1745-1770.

Stead, R. 1996. Foundation Quantitative Methods for Business. England: Prentice Hall.

Tahir, M., Hasnu, S., Estrada, M.R. 2018. Macroeconomic determinants of trade openness: Empirical investigation SAARC region. Journal of Asia Business Studies, 12(2), 151-161.

Tembo, J. 2018. Regional financial integration and its impact on financial sector development: The case of Southern Africa. Unpublished Doctoral Thesis, University of South Africa.

Tsaurai, K. 2018. Complementarity between foreign aid and financial development as a driver of economic growth in selected transitional economies. Comparative Economic Research. Central and Eastern Europe, 21(4), 45-61.

Ulaşan, B. 2015. Trade openness and economic growth: Panel evidence. Applied Economics Letters, 22, 163-167.

Yanikkaya, H. 2003. Trade openness and economic growth: a cross-country empirical investigation. Journal of development Economics, 72, 57-89.

Zannou, A. 2010. Determinants of Intra-ECOWAS trade flows. African Journal of Business Management, 4, 678-686. 